\title{
EFFECT OF CONSTANT LENGTH OF DAY ON REPRODUCTION IN ALBINO MICE
}

\author{
BY SUE FLICK MATHEWSON, DAVID E. DAVIS \\ The Johns Hopkins School of Hygiene and Public Health \\ AND JOHN J. CHRISTIAN \\ Naval Medical Research Institute, Bethesda, Maryland
}

(With 3 Figures in the Text)

\section{INTRODUCTION}

The purpose of this study was to investigate seasonal changes in reproduction in a colony of albino mice and to determine whether changes in production of young occurred when the length of daylight was made constant. The study covered a period of 2 and $1 \frac{1}{2}$ years, from January 1952 to May 1954, and includes data on almost 16,000 litters of mice. Specifically, the objectives were to examine the following aspects of reproduction: changes in litter size according to month and parity, the percentage of animals that become pregnant again at the first postpartum oestrus, the duration of the post-partum pregnancy, and the age at first parity. All these aspects were investigated before and after the change was made from normal, seasonal, variation in length of daylight to a controlled, constant, length of daylight in the animal room. This change was made about half-way through the experiment, on 1 June 1953.

\section{METHODS}

The mouse colony was the regular stock colony of the Naval Medical Research Institute, Bethesda, Maryland. Each pair of mice was kept in a metal box under relatively constant conditions. The temperature in the animal room was kept between 75 and $85^{\circ} \mathrm{F}$., but humidity was not controlled. Light was not regulated until 1 June 1953, when $15 \mathrm{hr}$. per day of fluorescent light was made constant. The mice were fed Rockland mouse food throughout the experiment. Sawdust in the metal boxes was changed twice a week.

Siblings were always paired, and the young were weaned at 20 days of age. A tendency existed for selection of animals with large litters to be kept for breeding. This factor might have influenced the genetic constitution of the colony.

Records for each female were kept on a card placed on her cage. The card gave the date of birth of the mother, the date each litter was born, the number of young born, and the number weaned. (No more than ten young were weaned from a litter; the excess young were discarded.) From these data, changes in litter size according to parity and according to month, intervals between litters, duration of post-partum pregnancy, and age at first parity were determined. A total of 14,405 litters was analysed. 
From the information on the cards, the mean number of young in each litter according to parity (i.e. the number of times the female had borne a litter) was tabulated. The results are given in Tables $1 a$ and $b$, and are shown in graph form in Fig. 1. It can be easily seen from Fig. 1 that no consistent seasonal trend occurs in average litter size. Likewise, examination of the data in Tables $1 a$ and $b$ indicate no seasonal trends in litter size according to parity. Since such large

Table 1a. Litter sizes of albino mice according to year, month and parity (before constant length of day)

\begin{tabular}{|c|c|c|c|c|c|c|c|c|c|c|c|c|c|}
\hline \multirow[b]{2}{*}{ Year } & \multirow[b]{2}{*}{ Month } & \multicolumn{11}{|c|}{ Parity number } & \multirow[b]{2}{*}{ Mean } \\
\hline & & 1 & 2 & 3 & 4 & 5 & 6 & 7 & 8 & 9 & 10 & 11 & \\
\hline \multirow[t]{12}{*}{1952} & Jan. & $8 \cdot 2$ & $8 \cdot 6$ & $8 \cdot 6$ & $7 \cdot 7$ & $8 \cdot 0$ & $7 \cdot 6$ & $6 \cdot 6$ & $8 \cdot 7$ & $8 \cdot 5$ & - & 一 & 8.06 \\
\hline & Feb. & $8 \cdot 3$ & $8 \cdot 7$ & $8 \cdot 2$ & $8 \cdot 5$ & $8 \cdot 2$ & $7 \cdot 9$ & $7 \cdot 0$ & $7 \cdot 7$ & $7 \cdot 4$ & - & - & $7 \cdot 99$ \\
\hline & Mar. & $7 \cdot 8$ & $8 \cdot 7$ & $8 \cdot 3$ & $8 \cdot 2$ & $7 \cdot 6$ & $8 \cdot 2$ & $7 \cdot 6$ & $6 \cdot 7$ & $6 \cdot 7$ & $7 \cdot 3$ & 一 & $7 \cdot 71$ \\
\hline & Apr. & $8 \cdot 4$ & $8 \cdot 9$ & $8 \cdot 7$ & $8 \cdot 8$ & $9 \cdot 0$ & $7 \cdot 1$ & $7 \cdot 2$ & $6 \cdot 6$ & $5 \cdot 6$ & $6 \cdot 5$ & $6 \cdot 3$ & $7 \cdot 55$ \\
\hline & May & $8 \cdot 2$ & $8 \cdot 7$ & $8 \cdot 4$ & $9 \cdot 1$ & $8 \cdot 5$ & $8 \cdot 8$ & $6 \cdot 9$ & $7 \cdot 0$ & $6 \cdot 5$ & $5 \cdot 0$ & $6 \cdot 7$ & $7 \cdot 62$ \\
\hline & June & $8 \cdot 7$ & $9 \cdot 0$ & $8 \cdot 7$ & $10 \cdot 2$ & $8 \cdot 8$ & $7 \cdot 4$ & $8 \cdot 0$ & $6 \cdot 5$ & $6 \cdot 4$ & $5 \cdot 1$ & $6 \cdot 2$ & $7 \cdot 73$ \\
\hline & July & $8 \cdot 2$ & $8 \cdot 6$ & $9 \cdot 0$ & 8.3 & $8 \cdot 3$ & 8.5 & $7 \cdot 2$ & $7 \cdot 1$ & $7 \cdot 3$ & $5 \cdot 6$ & - & $7 \cdot 81$ \\
\hline & Aug. & $8 \cdot 0$ & $9 \cdot 3$ & $9 \cdot 3$ & $8 \cdot 2$ & $7 \cdot 9$ & $8 \cdot 6$ & $8 \cdot 8$ & $7 \cdot 0$ & $5 \cdot 6$ & - & - & 8.08 \\
\hline & Sept. & $7 \cdot 3$ & $8 \cdot 5$ & $9 \cdot 3$ & 8.7 & $8 \cdot 5$ & $7 \cdot 9$ & $7 \cdot 8$ & $7 \cdot 2$ & $7 \cdot 4$ & $8 \cdot 1$ & - & 8.07 \\
\hline & Oct. & $7 \cdot 7$ & $7 \cdot 8$ & $7 \cdot 7$ & $9 \cdot 1$ & $9 \cdot 1$ & $8 \cdot 6$ & $7 \cdot 8$ & $7 \cdot 0$ & $5 \cdot 5$ & $6 \cdot 1$ & $4 \cdot 4$ & $7 \cdot 34$ \\
\hline & Nov. & $7 \cdot 8$ & $8 \cdot 6$ & $8 \cdot 5$ & $8 \cdot 7$ & $9 \cdot 1$ & $8 \cdot 5$ & $7 \cdot 9$ & $6 \cdot 7$ & $6 \cdot 6$ & 6.5 & $4 \cdot 7$ & $7 \cdot 60$ \\
\hline & Dec. & $8 \cdot 4$ & 8.5 & $8 \cdot 3$ & $9 \cdot 1$ & $7 \cdot 9$ & $8 \cdot 0$ & $7 \cdot 5$ & $7 \cdot 0$ & $6 \cdot 9$ & 5.4 & $6 \cdot 6$ & $7 \cdot 60$ \\
\hline \multirow[t]{6}{*}{1953} & Jan. & $7 \cdot 7$ & $8 \cdot 3$ & $8 \cdot 6$ & 8.5 & $8 \cdot 3$ & $7 \cdot 8$ & $7 \cdot 0$ & $7 \cdot 2$ & $7 \cdot 0$ & $6 \cdot 5$ & - & $7 \cdot 69$ \\
\hline & Feb. & $7 \cdot 8$ & $8 \cdot 3$ & $8 \cdot 3$ & $7 \cdot 6$ & $7 \cdot 9$ & $6 \cdot 9$ & $8 \cdot 2$ & $7 \cdot 4$ & 6.8 & $6 \cdot 9$ & $6 \cdot 2$ & $7 \cdot 48$ \\
\hline & Mar. & $7 \cdot 8$ & $8 \cdot 4$ & $8 \cdot 9$ & $8 \cdot 9$ & $8 \cdot 4$ & $7 \cdot 2$ & $6 \cdot 8$ & $7 \cdot 1$ & $6 \cdot 2$ & $7 \cdot 1$ & $5 \cdot 7$ & $7 \cdot 49$ \\
\hline & Apr. & $8 \cdot 2$ & $8 \cdot 8$ & $8 \cdot 7$ & $9 \cdot 0$ & $8 \cdot 6$ & $8 \cdot 0$ & $7 \cdot 9$ & $7 \cdot 8$ & $6 \cdot 9$ & $7 \cdot 4$ & - & $8 \cdot 13$ \\
\hline & May & $7 \cdot 7$ & $8 \cdot 3$ & $8 \cdot 6$ & $8 \cdot 3$ & $8 \cdot 4$ & $7 \cdot 9$ & $7 \cdot 3$ & $7 \cdot 4$ & $5 \cdot 5$ & - & - & $7 \cdot 71$ \\
\hline & June & $8 \cdot 0$ & 8.5 & $8 \cdot 3$ & $8 \cdot 6$ & $7 \cdot 6$ & $7 \cdot 9$ & $8 \cdot 1$ & $6 \cdot 4$ & $7 \cdot 6$ & - & - & $7 \cdot 89$ \\
\hline Total & & 8.01 & 8.58 & 8.58 & $8 \cdot 64$ & $8 \cdot 34$ & $7 \cdot 93$ & $7 \cdot 53$ & $7 \cdot 14$ & $6 \cdot 67$ & $6 \cdot 42$ & $5 \cdot 85$ & $7 \cdot 75$ \\
\hline
\end{tabular}

Table 1b. Litter sizes of albino mice according to year, month and parity (length of day constant at $15 \mathrm{hr}$.)

Parity number

\begin{tabular}{|c|c|c|c|c|c|c|c|c|c|c|c|c|c|}
\hline Year & Month & 1 & 2 & 3 & 4 & 5 & 6 & 7 & 8 & 9 & 10 & 11 & Mean \\
\hline \multirow{7}{*}{1953} & June & 8.9 & $7 \cdot 5$ & $8 \cdot 5$ & $9 \cdot 4$ & $8 \cdot 0$ & $8 \cdot 2$ & $8 \cdot 0$ & - & - & - & - & $8 \cdot 36$ \\
\hline & July & $7 \cdot 7$ & $7 \cdot 9$ & $8 \cdot 5$ & $8 \cdot 4$ & $8 \cdot 5$ & $8 \cdot 3$ & 7.5 & $7 \cdot 2$ & $6 \cdot 3$ & $8 \cdot 3$ & - & $7 \cdot 86$ \\
\hline & Aug. & $7 \cdot 8$ & $8 \cdot 4$ & $8 \cdot 0$ & $8 \cdot 6$ & $8 \cdot 2$ & $7 \cdot 9$ & $7 \cdot 3$ & 6.9 & $7 \cdot 3$ & $6 \cdot 7$ & - & $7 \cdot 71$ \\
\hline & Sept. & $7 \cdot 2$ & $9 \cdot 0$ & $9 \cdot 1$ & $7 \cdot 8$ & $8 \cdot 4$ & $8 \cdot 2$ & $8 \cdot 2$ & $7 \cdot 2$ & $8 \cdot 3$ & $7 \cdot 1$ & $\longrightarrow$ & $8 \cdot 03$ \\
\hline & Oct. & 8.5 & $8 \cdot 6$ & $8 \cdot 4$ & $8 \cdot 0$ & $7 \cdot 5$ & $8 \cdot 2$ & $8 \cdot 0$ & $6 \cdot 8$ & $6 \cdot 8$ & $5 \cdot 7$ & - & $7 \cdot 65$ \\
\hline & Nov. & $8 \cdot 2$ & $7 \cdot 7$ & $8 \cdot t$ & 8.9 & $8 \cdot 5$ & $7 \cdot 9$ & $7 \cdot 3$ & $7 \cdot 2$ & $6 \cdot 9$ & $6 \cdot 6$ & - & $7 \cdot 78$ \\
\hline & Dec. & $7 \cdot 6$ & $7 \cdot 8$ & $9 \cdot 2$ & $7 \cdot 7$ & $8 \cdot 5$ & $7 \cdot 7$ & $7 \cdot 2$ & $7 \cdot 3$ & $5 \cdot 7$ & $5 \cdot 5$ & - & $7 \cdot 42$ \\
\hline \multirow[t]{5}{*}{1954} & Jan. & $7 \cdot 5$ & $9 \cdot 1$ & $7 \cdot 5$ & $8 \cdot 6$ & $9 \cdot 4$ & $8 \cdot 4$ & $7 \cdot 5$ & $7 \cdot 6$ & 6.5 & $6 \cdot 2$ & - & $7 \cdot 83$ \\
\hline & Feb. & $7 \cdot 1$ & $7 \cdot 7$ & $9 \cdot \mathrm{C}$ & $9 \cdot 6$ & $8 \cdot 8$ & $8 \cdot 6$ & $7 \cdot 7$ & $7 \cdot 0$ & & 6 . & - & $7 \cdot 92$ \\
\hline & Mar. & - & $8 \cdot 5$ & $8 \cdot 3$ & 8.7 & $9 \cdot 4$ & $7 \cdot 3$ & $7 \cdot 8$ & $7 \cdot 0$ & 6.0 & $6 \cdot 2$ & 6.4 & $7 \cdot 56$ \\
\hline & Apr. & - & - & - & $7 \cdot 7$ & $8 \cdot 3$ & $8 \cdot 5$ & $6 \cdot 0$ & $5 \cdot 6$ & $5 \cdot 0$ & $6 \cdot 9$ & $6 \cdot 0$ & $6 \cdot 75$ \\
\hline & May & - & - & - & - & $7 \cdot 5$ & 9.9 & $7 \cdot 8$ & 6.6 & $4 \cdot 8$ & - & - & $7 \cdot 32$ \\
\hline Cotal & & $7 \cdot 83$ & 8.22 & 8.51 & $8 \cdot 49$ & $8 \cdot 42$ & $8 \cdot 26$ & $7 \cdot 53$ & 6.95 & 6.44 & $6 \cdot 58$ & $6 \cdot 20$ & $7 \cdot 70$ \\
\hline
\end{tabular}


numbers of litters were available, and since the number of litters in each month was about the same, it seemed unnecessary to calculate the standard deviations for each month. However, these values were calculated for several months and the deviations fell between $2 \cdot 5$ and $3 \cdot 0$. From this it can be said that a difference of 0.7 embryos between 2 -monthly averages in Tables $1 a$ and $b$ is statistically significant at the 0.05 level.

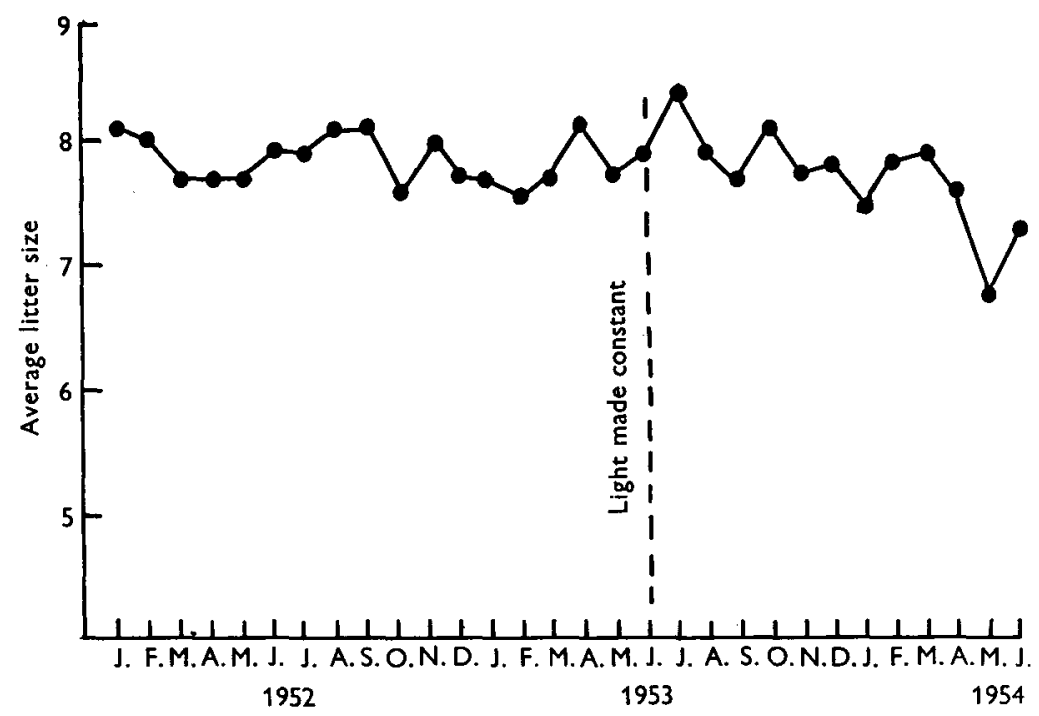

Fig. 1. Average litter size for 18 months under normal length of day and for 12 months under $15 \mathrm{hr}$. length of day.

The data for all litters were averaged according to parity and it is apparent from Fig. 2 that the productivity of the female reaches a peak at the third or fourth pregnancy and then steadily declines with each succeeding pregnancy. A difference of $0 \cdot 1$ embryo is significant in these data.

These data also indicate that there was no apparent change in productivity due to the change to constant period of light (15 hr. per day) after 1 June 1953. The average number of mice per litter for the whole period before light was made constant was $7 \cdot 75$; after light was made constant the average was $7 \cdot 70$.

More interesting information is to be gained from the data on interval between litters. The number of days between litters was tabulated according to parity for each month. Intervals of 20 days up to 60 days were recorded. Previous work (Snell, 1941) has shown that white mice come into oestrus again within $20 \mathrm{hr}$. after parturition, and, if a fertile mating takes place at this time, implantation occurs within about 5 days. (Implantation occurs later if the female is suckling a large litter. See Bruce \& East, 1956.) The gestation period is 19-20 days. Thus there is a total interval of 20-30 days from the birth of one litter to the birth of the next if a fertile mating follows parturition. Therefore, the data on intervals between litters were divided into intervals less than 31 days and intervals between 31 and 61 days. Thus the number under 31 days divided by the total number gave the percentage of mice that were fertilized during the post-partum oestrus. This 
percentage ranges from $52 \cdot 6$ to $72 \cdot 8 \%$ over the 30 -month period, as is shown in Fig. 3. (The low figure of $52 \cdot 6 \%$ occurred in December 1952, and coincided with the time when construction work was being done near the laboratory. It was suggested that the noise and general confusion of this work contributed significantly to lowering the percentage of animals which were able to mate successfully after parturition.)

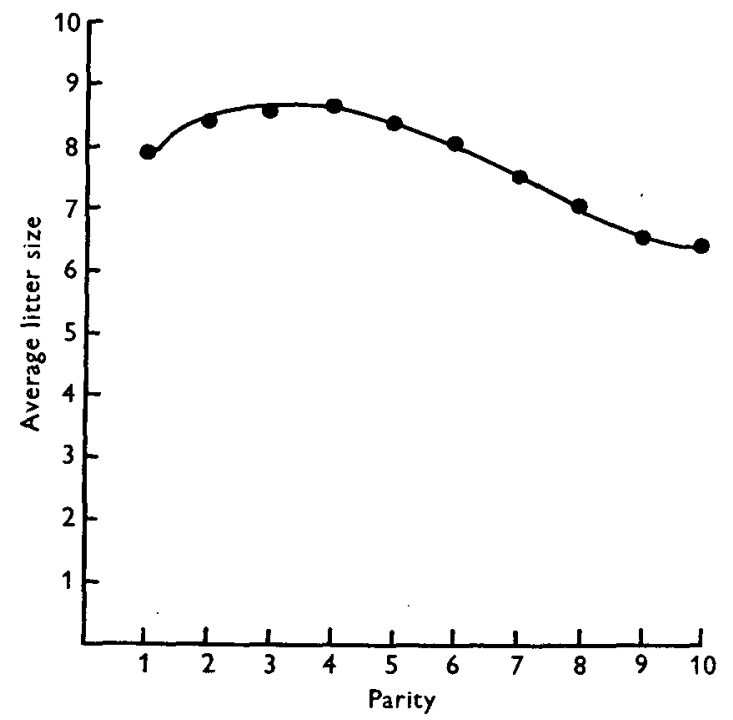

Fig. 2. The average size of litter according to order of litter.

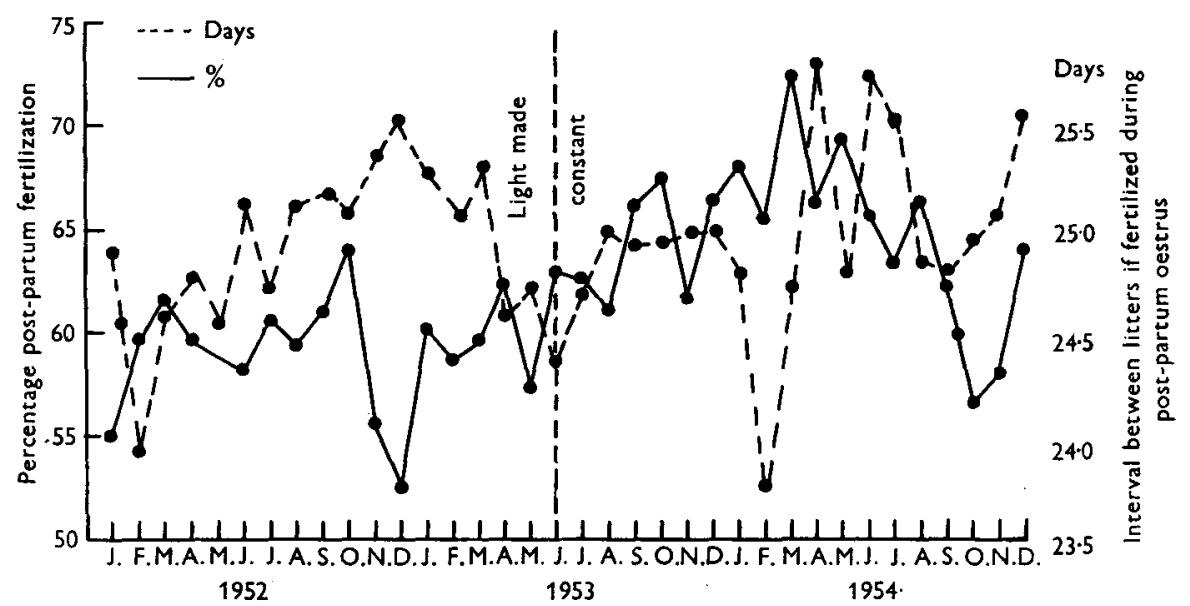

Fig. 3. Comparison of fertilization at post-partum oestrus before and after the length of day was made constant at $15 \mathrm{hr}$.

A comparison of the percentage of post-partum pregnancies before and after constant day length shows that there is a significantly larger percentage for the period July 1953-June 1954 than for the previous year July 1952-June 1953. The total percentage of post-partum pregnancies for the year before light was made constant was $59.6 \%$; for the year after, $65.7 \%$. This increase is significant at the 
0.01 level. Also the percentage for only June and July of 1952 and 1953 was compared with that for June and July 1954. The post-partum pregnancies increased from $61.3 \%$ in June-July $1952-53$ to $65.0 \%$ in June-July 1954. However, this increase is not significant at the 0.05 level. Nevertheless, these data suggest that there was an increase in percentage of post-partum pregnancies coincident with making the number of hours of light constant each day.

The duration of pregnancy was determined for all months for females that became pregnant at the post-partum oestrus (and thus gave birth to the next litter between 18-31 days post-partum). Between 250-300 litters were available in each month and a difference of 0.2 days is statistically significant at the $5 \%$ level. The data are graphed in Fig. 3 and show no consistent seasonal trends or a change after the length of day was made constant. Some erratic changes occur and presumably are due to some variable such as change in caretakers, construction, accidents, or other factors.

Table 2. The average age (weeks) at first parturition

$\begin{array}{rrrrr}\text { Year } & \text { May } & \text { June } & \text { July } & \text { Aug. } \\ 1952 & 10 \cdot 23 & 9 \cdot 90 & 10.04 & 10 \cdot 50 \\ 1953 & 9 \cdot 97 & 9 \cdot 83 & 11 \cdot 10 & 10 \cdot 41 \\ 1954 & 9 \cdot 57 & 9 \cdot 57 & 9 \cdot 53 & 9 \cdot 13\end{array}$

The age at first parturition was determined only with respect to the change to constant level of daylight because no seasonal trend had been revealed thus far. Therefore, the age at first parturition of the females born in May, June, July and August of 1952, 1953 and 1954 was determined (Table 2). A difference of 0.5 weeks is statistically significant. The only noteworthy month was July 1953; during that period females were older at first parturition. It should be noted that this time was the first month that length of daylight was made constant.

\section{SUMMARY}

Studies on reproduction in a colony of albino mice before and after length of daylight was made constant show no change in litter size. However, there was an increase in the number of post-partum pregnancies after light was made constant and, during the first month thereafter, females were older at first parturition than in previous months.

\section{REFERENCES}

Brtae, HItdA M. \& EAST, JUNE (1956). Number and viability of young from pregnancies concurrent with lactation in the mouse. J. Endocrin. 14, 19.

Snedr, Georat D. (ed.) (1941). Biology of the Laboratory Mouse, 497 pp. Philadelphia: The Blakiston Co.

(MS. received for publication 13. I. 59) 